\title{
Scale analysis of carabids richness (Coleoptera: Carabidae) in southern South America
}

\section{Análisis de escala de la riqueza de carábidos (Coleoptera: Carabidae) en América del Sur austral}

\author{
Christian Muñoz-Escobar ${ }^{1,2,3^{*}}$, Sergio Roig-Juñent ${ }^{4}$, Rodolfo Carrara $^{4}$ \& Viviane Jerez ${ }^{2,3}$ \\ ${ }^{1}$ Programa de Doctorado en Sistemática y Biodiversidad. \\ 2Departamento de Zoología. Facultad de Ciencias Naturales y Oceanográficas. Universidad de Concepción, Concepción, Chile. \\ ${ }^{3}$ Red Chilena Entomológica de la Conservación (RECEC) \\ ${ }^{4}$ Instituto Argentino de Investigaciones de las Zonas Áridas (IADIZA), Mendoza, Argentina. \\ *christianmz@gmail.com
}

\begin{abstract}
The southern South America presents a complex history of geomorphological and climatic events, which have modulated and fragmented the southwestern part of the Andes mostly. Given the complexity of the southern landscape, the analysis of the hierarchical components alpha- $\alpha$, beta- $\beta$ and gamma- $\gamma$ on carabid diversity allows exploring the responses of species to spatial changes patterns according to the scales of the landscape. In order to understand how spatial scales influence the carabid diversity in southern South America, we used an approach at multiple spatial scales of multiplicative diversity partitioning. We included four spatial scales in our analysis: among $0.25^{\circ}$ quadrats, $0.5^{\circ}$ quadrats, provinces and biogeographic sub-regions. The results showed that the pattern of carabid distribution is not random, and varies according to the spatial scale. At larger scales $\beta$-diversities are observed to be higher than expected, but lower than expected at smaller scales. This suggests that carabid ensembles are more homogenous than expected, particularly at the scale of $0.5^{\circ}$ quadrats. As explanatory factors, glacial/post-glacial events and historical processes may have had an impact on the present species patterns. Furthermore, due to the importance of beta- $\beta$ diversity on local and regional scales, a promising approach for future studies is to investigate which biogeographic mechanisms seem to determine the species distribution in different provinces.
\end{abstract}

KeYwords: Beta diversity, Multiplicative partitioning, Island Systems, Chile.

\section{RESUMEN}

La compleja historia geomorfológica y climática de Sudamérica austral ha modulado y fragmentado particularmente el sector sur de los Andes. Dada la complejidad del paisaje austral, un análisis de los componentes de diversidad alfa- $\alpha$, beta- $\beta$ and gamma- $\gamma$ de carábidos, permite explorar los cambios de los patrones espaciales considerando las escalas de paisaje. Para analizar el efecto de la escala espacial sobre la diversidad de carábidos en Sudamérica austral, realizamos un particionamiento multiplicativo de diversidad. Para nuestro análisis incluimos cuatro escalas espaciales, cuadrículas de $0,25^{\circ}$, cuadrículas $0,5^{\circ}$, provincias biogeográficas y subregiones biogeográficas. Nuestros resultados muestran que el patrón de distribución de carábidos no es aleatorio. A gran escala se observa que las diversidades beta son mayores a lo esperado, mientras a baja escala son menores a lo esperado. Lo anterior sugiere que los ensambles de carábidos son más homogéneos, principalmente entre cuadrículas de $0,5^{\circ}$. Discutimos el efecto de procesos históricos en el patrón actual de especies. Debido a la importancia de la diversidad beta- $\beta$ a escala local y regional, es que se da pie a una interesante línea de investigación para entender que mecanismos biogeográficos parecen determinar la distribución de especies en diferentes provincias.

Palabras Claves: Diversidad beta, Particionamiento multiplicativo, Sistemas insulares, Chile.

\section{INTRODUCTION}

The carabids (Coleoptera: Carabidae) are one of the most diversified animal groups in the terrestrial ecosystems of southern South America (Roig-Juñent \& Domínguez 2001). Associated mainly with the Valdivian Forest and sub-
Antarctic forests (Kuschel 1960), they are characterized by presenting endemic tribes (e.g. Migadopini, Ceroglossini), monotypic genera and species with relict distribution (Darlington 1965). These insects are good indicators of past terrestrial environments (Elias 2007), since they are highly mobile and thereby able to respond rapidly to environmental 
change by rapidly shifting its distribution patterns; they are also very abundant and have a well-preserved fossil record, since it is feasible to find almost all current species in ensembles of the Quaternary (Ashworth et al. 1991; Ashworth 2007).

Moreover, carabid beetles are ideal candidates to study nonrandom species distributions (Magura et al. 2001), manifested as particular metacommunity structures that represent the dynamics of diversity at local and landscape scales (Fournier \& Loreau 2001). The scale dependence of carabid diversity has broad implications for biogeography, where the contemporary distribution patterns reflect biological and physical processes operating at multiple spatial scales, over both evolutionary and ecological time scales (Holling 1992). This is particularly interesting if we consider highly fragmented areas such as southern South America. This sector was broadly impacted by geological and paleoclimatic events which dramatically altered the landscape of southern Patagonia, and have impacted the abundance and distribution of the biota (Hinojosa \& Villagrán 1997; Ashworth 2007).

In order to understand the currently uneven spatial distribution of species and how spatial scales influence the carabid diversity in southern South America, a focus at multiple scales it is required to study hierarchical/nested systems (Holling 1992). The hierarchical approximation proposed by Whittaker $(1960,1972)$ relates the composition and variability of local communities to that of regional ensembles. This author recognized a connection between the spatial scale and species richness in the hierarchical components of alpha ( $\alpha$, local or intra-site), beta ( $\beta$, between sites) and gamma ( $\gamma$, regional) diversity. The importance of this approximation lies in the definition of $\beta$-diversity as a measure of the variation in species composition between ensembles (Whittaker 1960). Whittaker (1972) suggested that gamma is the product of alpha and beta $(\gamma=\alpha * \beta)$, considering $\beta$-diversity to be a comparison of the number of species at different spatial scales $(\beta=\gamma / \bar{\alpha}-1)$.

One of the main approaches to conceptualize spatial variation in $\beta$-diversity it is the partitioning of species diversity $(\gamma)$ into alpha and beta components (Crist et al. 2003; Chao et al. 2012). Partitioning the regional diversity of carabids into its average $\bar{\alpha}$-diversity (local diversity) component and the amount of variation between ensembles ( $\beta$-diversities) across multiple scales of sampling (i.e. sampling units that are progressively aggregated upwards), can give insight into the scales at which $\beta$-diversity might be higher or lower (Barton et al. 2013). This is important especially in fragmented environments, given that the responses of species to spatial changes may vary depending on the scales of the landscape (Pardini et al. 2010). The objectives of our study are to partitioning gamma diversity components of carabid beetles across hierarchical spatial scales in the highly fragmented landscape in southern South America, and to determine which spatial scale contributes the most to the species richness.

\section{MATERIALS AND METHODS}

\section{CARABid BeEtles Database}

Our database included a total of 3955 geo-referenced records for 180 species of Carabidae. Thus, we worked with the complete distribution of those species that inhabit areas that were affected by the Last Glacial Maximum (LGM) and that are endemic to the Andean Region. The information was obtained by a review of five institutional collections. In Chile: Museo Nacional de Historia Natural (MNNC); Museo Entomológico Luis Peña (MEUC); Instituto de Entomología de la Universidad Metropolitana de Ciencias de la Educación (UMCE); Museo de Zoología, Universidad de Concepción (UCCC) and Instituto de la Patagonia (IPUM). In Argentina: Instituto Argentino de Investigaciones de las Zonas Áridas (IADIZA).

We also compiled information on locality recordings from scientific publications (Jeannel 1962; Straneo 1979; Niemelä 1990; Roig-Juñent 1993, 2000, 2004; Roig-Juñent \& Domínguez 2001; Jiroux 2006; Allegro et al. 2008; Elgueta et al. 2013, among others) and from a number of samplings we performed: Región de Los Lagos: Parque Katalapi, Isla de Chiloé. Región de Aysén: valleys of the Aysén, Cóndor, Cuervo, Blanco, Baker and Pascua Rivers. Región de Magallanes: Parque Nacional Bernardo O'Higgins (PNBO), Reserva Nacional Alacalufes (sector Canal de las Montañas), Área Marina Costera Protegida Francisco Coloane (AMCP), Brunswick Península (Sector de San Juan), Parque Karukinka (Tierra del Fuego) and Parque Etnobotánico Omora (Isla Navarino).

\section{DIVERSITY PARTITIONING}

In order to rank the different spatial scales in terms of their importance to carabid species, we performed a multiplicative diversity partitioning (Jost 2007) based on Hill numbers $\left({ }^{\mathrm{q}} \mathrm{D}\right)$ (Hill 1973). In this case, the parameter q determines the sensitivity of the index to the relative frequencies of the species (Chao et al. 2012). The advantage of this approximation is that ${ }^{\mathrm{C}} \mathrm{D}$ is a measure of "true diversity" (effective number of communities), assuring independence between $\alpha$ and $\beta$, and allows the quantification of the heterogeneity of a region (Jost 2007; Chao et al. 2012). Since we worked with species records, we used a q value of order $0\left({ }^{9} \mathrm{D}=0\right)$. Thus, we performed a partitioning of total richness $\left({ }^{0} \mathrm{D}_{\gamma}\right)$ into local $\bar{\alpha}$-diversity $\left({ }^{0} \mathrm{D}_{\bar{\alpha}}\right)$ and $\beta$-diversities $\left({ }^{0} \mathrm{D}_{\beta}\right)$ components, using an unbalanced sampling design 
that involves different spatial scales.

According to our geographical context, we divided the area into quadrats, recording the presence of each species and information on the province and biogeographic sub-region (according to Morrone 2006) with which the quadrats intersects. Hence, the geographic system was divided into four hierarchical scales: quadrats of $0.25^{\circ}$, quadrats of $0.5^{\circ}$, biogeographic provinces and biogeographic sub-regions. Carabid diversity was determined as ${ }^{0} \mathrm{D}_{\gamma}={ }^{0} \mathrm{D}_{\bar{\alpha} 1}$ (average diversity within of $0.25^{\circ}$ quadrats) $\times{ }^{0} \mathrm{D}_{\beta 1}$ (among $0.25^{\circ}$ quadrats) $\times{ }^{0} \mathrm{D}_{\beta 2}$ (among $0.5^{\circ}$ quadrats) $\times{ }^{0} \mathrm{D}_{\beta 3}$ (among provinces) $x^{0} D_{\beta 4}$ (among subregions).

To evaluate if the observed diversity components differ from those expected by chance, we generated a null model using a randomization process of individuals among samples of all the hierarchical levels (Crist et al. 2003). We selected this model since it allows the identification of how the inter-specific spatial aggregation patterns may modulate the partitioning (Crist et al. 2003). To generate the frequency distribution of null data we performed 10,000 iterations. This allows estimating the probability that the observed diversity component is greater, equal to or less than expected by chance. This analysis was performed in the PARTITION 3.0 program (Veech \& Crist 2009).

\section{RESULTS}

The total $\gamma$-diversity $\left({ }^{0} \mathrm{D}_{\gamma}\right)$ of the southern South America was mainly attributed to $\beta$-diversity. The beta components $\left({ }^{0} \mathrm{D}_{\beta}\right)$ explained $75.81 \%$ (Table 1) among its different spatial scales (Fig. 1). The $0.25^{\circ}$ quadrats $\left({ }^{0} \mathrm{D}_{\beta 1}\right)$ explained $7.84 \%$; the $0.5^{\circ}$ quadrats $\left({ }^{0} \mathrm{D}_{\beta 2}\right) 47.6 \%$; the biogeographic provinces $\left({ }^{0} \mathrm{D}_{\beta 3}\right) \quad 11.49 \%$ and among biogeographic regions $\left({ }^{0} \mathrm{D}_{\beta 4}\right) 8.89 \%$. Although the greatest source of diversity was at the scale of $0.5^{\circ}$ quadrats $\left(\beta_{2}\right)$, both at this level and at the finer scale $\left(\beta_{1}\right)$, the observed values were significantly lower than expected under the null distribution (Fig. 1). However, at the scale of provinces and sub-regions the observed values were significantly greater than expected by chance. The $\bar{\alpha}$-diversity was also significantly greater than expected by chance; it explained $24.19 \%$ of the total diversity with a mean of 4.38 species per $0.25^{\circ}$ quadrat (Table 1 ).

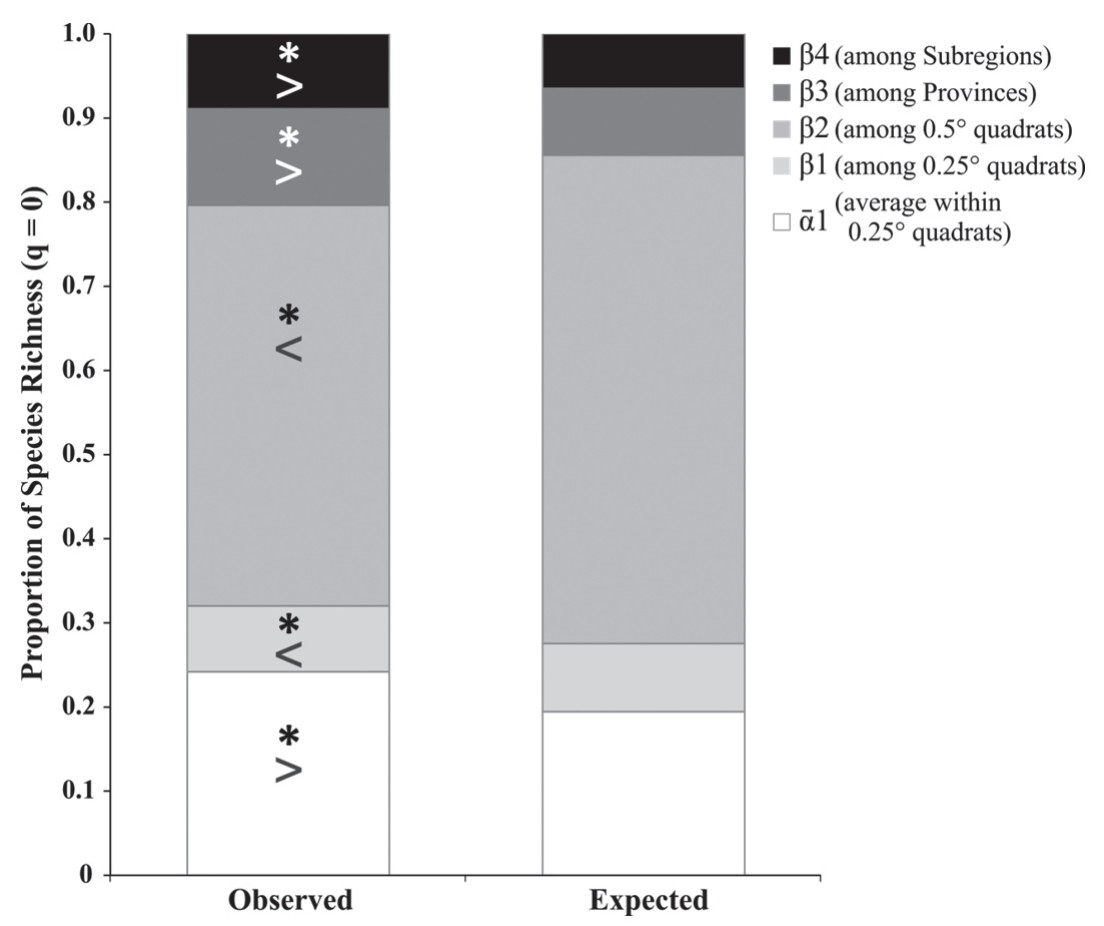

FIGURE 1. Multiplicative diversity partitioning of carabids based on species richness $(\mathrm{q}=0)$ at the Andean Region scale. Asterisks $(*)$ indicate proportions with significant values $(\mathrm{p}<0.001)$ in all cases. Symbols $>/<$ represent greater or lower values than expected.

Figura 1. Particionamiento multiplicativo de la diversidad de carábidos basado en la riqueza específica (q=0) a escala de la Región Andina. Asteriscos $(*)$ representan proporciones con valores significativos $(\mathrm{p}<0,001)$. Símbolos $>/<$, representan valores mayores o menores a lo esperado respectivamente. 
TABLE 1. Multiplicative diversity partitioning of carabids based on species richness $(\mathrm{q}=0)$ at the Andean region scale.

TABLA 1. Particionamiento multiplicativo de la diversidad de carábidos basado en la riqueza específica (q=0) a escala de la Región Andina.

\begin{tabular}{|c|c|c|c|c|c|}
\hline \multirow{2}{*}{$q=0$} & & \multirow{2}{*}{ OBSERVED } & \multirow{2}{*}{$\%$} & \multicolumn{2}{|c|}{ EXPECTED } \\
\hline & & & & MEAN & INTERVAL \\
\hline $\bar{\alpha} 1$ & average within $0.25^{\circ}$ quadrats & $4.38 *$ & 24.19 & 4.03 & $3.96-4.11$ \\
\hline$\beta 1$ & among $0.25^{\circ}$ quadrats & $1.42 *$ & 7.84 & 1.68 & $1.65-1.71$ \\
\hline$\beta 2$ & among $0.5^{\circ}$ quadrats & $8.62 *$ & 47.60 & 12.04 & $11.43-12.63$ \\
\hline$\beta 3$ & among Provinces & $2.08^{*}$ & 11.49 & 1.65 & $1.57-1.73$ \\
\hline$\beta 4$ & among Subregions & $1.61 *$ & 8.89 & 1.34 & $1.27-1.41$ \\
\hline$\gamma$ & Andean region & 1.0 & & 1.0 & $1.0-1.0$ \\
\hline
\end{tabular}

\section{DISCUSSION}

Our analysis of hierarchical components showed that the pattern of carabid distribution in southern South America is not random, and varies according to the spatial scale. Gering et al. (2003) have detected these scale dependent differences in spatial patterns of diversity for beetles. These authors found that a significant percentage of total species richness was attributed to $\beta$-diversity between ecoregions and, to a lesser extent, among sites. Likewise, our results shown that at larger scales (province and biogeographic sub-region) observed $\beta$-diversities were higher than expected (from a random distribution), but lower than expected at smaller scales $\left(0.25^{\circ}\right.$ and $0.5^{\circ}$ quadrats $)$. It is well established that different factors affect community assembly at different scales (Holling 1992). For instance, diversity at large scales is expected to be relatively different due to historical-geographical factors (Magura et al. 2001). Climatic filters and limited connectivity could be responsible for demographic isolation in some areas with an important number of unshared species (Fournier \& Loreau 2001).

We highlight the observed patterns of $\beta$-diversities at scales of $0.25^{\circ}$ and $0.5^{\circ}$ quadrats. Both components contributed over $55 \%$ to total diversity, but were lower than the expected by chance. This indicates that carabid species within each biogeographic province are a subsample of the same meta-community. Our result suggests the existence of continuous events of species immigration that would act as a homogenizing force among ensembles (Loreau \& Mouquet 1999; Fournier \& Loreau 2001). At lower scales, it seems that carabid beetles are not affected by the geographical fragmentation of southern South America. This could be explained because of the existence of habitat generalist carabids (Magura et al. 2001) and high dispersal trait is selected in unstable environments (Den Boer 1970). Other factors that could have contributed to carabids dispersion were the glacio-eustatic changes in sea level during quaternary. For instance, during LGM the lower sea level exposed the shelf around the Pacific Patagonian fjords (Ashworth et al. 1991) and later, postglacial isostatic rebound caused land mass elevations along shoreline terraces (Stern et al. 2011). Therefore, such areas probably served as land bridges allowing the movement of carabid beetles among the mainland and islands.

All the mentioned factors could explain why the $\bar{\alpha}$-diversity was higher than expected, since species immigration between spatial units raises the local diversity. This agrees with the suggestions of Massol et al. (2011) who indicated that the structure of local ensembles is influenced by regional processes. We propose that a source-sink meta-community dynamics (Mouquet \& Loreau 2003) or post-glacial dispersion would explain the pattern of greater richness at the local scale and less differentiation among quadrats than expected. This pattern suggests new hypotheses to account for the processes that explain the distribution pattern of carabids in southern South America. Moreover, we propose that regional processes (e.g. colonization, extinction) would be limiting factors in the replacement of species at large spatial scales (Massol et al. 2011; Barton et al. 2013), especially in fragmented environments (Magura et al. 2001) in which the meta-community dynamics determines the pattern of species distribution.

We emphasize the utility of partitioning diversity into its $\alpha$ and $\beta$ components, since this analysis allows new approximations to the study of diversity and explore the conceptual underpinnings of the spatial scaling in order to provide a better understanding of the ecological processes that sustain a widely distributed pattern. 


\section{ACKNOWLEDGEMENTS}

The authors thank the Corporación Nacional Forestal (CONAF), especially Jovito González, for support in the expedition to the Canal de las Montañas (R.N. Alacalufes). We thank the Centro de Estudios del Cuaternario (CEQUA), for their invitation and support in the expedition in the Parque Nacional Bernardo O'Higgins and the AMCP Francisco Coloane. We thank the Fundación Omora for collaboration and support in sampling of the Parque Etnobotánico Omora, and the Wildlife Conservation Society for their support in the sampling of Parque Karukinka (Tierra del Fuego), Dr. Lafayette Eaton and Javiera Alfaro who helped translating earlier versions of this manuscript. Finally C. MuñozEscobar is a student in the Doctoral Program in Systematics and Biodiversity and was supported by UdeC and CONICYT Doctoral Fellowships. This work was funded by project DIUC 212.113.080-1.0.

\section{BIBLIOGRAPHY}

Allegro, G., Giachino, P.M. \& Sciaky, R. 2008. Notes on some Trechini (Coleoptera, Carabidae) of South America with description of new species from Chile, Ecuador y Perú. Biodiversity of South America, I. Memoirs on Biodiversity 1:131-171.

Ashworth, A.C. 2007. Beetle Records - Late Pleistocene of South America. In: Encyclopedia of Quaternary Science (Ed. Elias, S.A.), pp 212-221. Elsevier Science Publishers B.V. Amsterdam, The Netherlands.

Ashworth, A.C., Markgraf, V. \& Villagran, C. 1991. Late Quaternary climatic history of the Chilean fjords based on fossil pollen and beetle analyses, with an analysis of the modern vegetation and pollen rain. Journal of Quaternary Science 6:279-291.

Barton, P.S., Cunningham, S.A., Manning, A.D., GibB, H., Lindenmayer, D.B. \& Didham, R.K. 2013. The spatial scaling of beta diversity. Global Ecology and Biogeography 22:639-647.

Chao, A., Chiv, C.H. \& Hsien, T.C. 2012. Proposing a resolution to debates on diversity partitioning. Ecology 93:2037-2051.

Crist, T.O., Veech, J.A., Gering, J.C. \& Summerville, K.S. 2003. Partitioning species diversity across Landscapes and Regions: A Hierarchical Analysis of $\alpha, \beta$, and $\gamma$ Diversity. The American Naturalist 162:734-743.

Darlington, P.J. 1965. Biogeography of the Southern End of the World. Distribution and history of far-southern life and land, with an assessment of continental drift. Harvard University Press. Cambridge, Massachusetts. xi +236 pp.

Den Boer, P.J. 1970. On the significance of dispersal power for populations of carabid-beetles (Coleoptera, Carabidae). Oecologia (Berl.) 4:1-28.

Elgueta, M., Flores, G.E. \& Roig-Juñent, S. 2013. Algunos coleópteros (Coleoptera: Carabidae, Promecheilidae) de Islas Diego Ramírez (56³2’S; 6843’W), Región de Magallanes. Anales Instituto Patagonia 41(1):141-146.

Elias, S.A. 2007. Beetle Records - Overview. In: Encyclopedia of
Quaternary Science (Ed. Elias, S.A.), pp 153-163. Elsevier Science Publishers B.V. Amsterdam, The Netherlands.

Fournier, E.\& LOREAU, M. 2001. Respective roles of recent hedges and forest patch remnants in themaintenance of groundbeetle (Coleoptera: Carabidae) diversity in an agricultural landscape. Landscape Ecology16:17-3.

Gering, J.C., Crist, T.O. \& VeECH, J.A. 2003. Additive partitioning of species diversity across multiple spatial scales: Implications for regional conservation of biodiversity. Conservation Biology 17(2):488-499.

HiLl, M.O. 1973. Diversity and evenness: A unifying notation and its consequences. Ecology 54(2):427-432.

Hinojosa, L.F. \& Villagrán, C. 1997. Historia de los bosques del sur de Sudamérica, I: antecedentes paleobotánicos, geológicos y climáticos del Terciario del cono sur de América. Revista Chilena de Historia Natural 70:225-239.

Holling, C.S. 1992. Cross-scale morphology, geometry, and dynamics of ecosystems. Ecological Monographs 62:447502.

JEAnNel, R. 1962. Les Trechides de la paleantarctide occidentale. En: Biologie de l'Amérique australe, tome 1 (Eds. Debouteville, C.D. \& E. Rapoport), pp 527-655. Éditions du Centre National de la Recherche Scientifique, Paris, Francia.

Jiroux, E. 2006. Le genre Ceroglossus. Collection Systématique. Vol 14. Magellanes. $173 \mathrm{pp}$.

Jost, L. 2007. Partitioning diversity into independent alpha and beta components. Ecology 88:2427-2439.

Kuschel, G. 1960. Terrestrial Zoology in Southern Chile. Proceedings of the Royal Society of London. Series B. Biological Sciences 152:540-550.

Loreau, M. \&Mouquet, N. 1999. Immigration and the maintenance of local species diversity. The American Naturalist 154(4):427-440.

Magura, T., KöDöвöcz, V. \& Tóthmérész, B. 2001. Effects of habitat fragmentation on carabids in forest patches. Journal of Biogeography 28:129-138.

Massol, F., Gravel, D., Mouquet, N., Cadotte, M.W., Fukami, T. \& Leibold, M.A. 2011. Linking community and ecosystem dynamics through spatial ecology. Ecology Letters 14:313323.

Morrone, J.J. 2006. Biogeographic areas and transition zones of Latin America and the Caribbean Islands, based on panbiogeographic and cladistic analyses of the entomofauna. Annual Review of Entomology 51:467-494.

Mouquet, N. \& Loreau, M. 2003. Community patterns in sourcesink metacommunities. American Naturalist 162:544-557.

NIEMELÄ, J. 1990. Habitat distribution of carabid beetles in Tierra del Fuego, South America. Entomologica Fennica 1:3-16.

Pardini, R., Bueno, A. D. A, Gardner, T.A., Prado, P.I. \&Metzger, J.P. 2010. Beyond the fragmentation threshold hypothesis: Regime shifts in biodiversity across fragmented landscapes. PLoS ONE 5(10): e13666.

RoIG-JuñEnt, S. 1993. Cnemalobini, una tribu de Carabidae (Coleoptera) endémica de América del Sur. Acta Entomológica Chilena 18:7-18.

RoIG-JuÑENT, S. 2000. The subtribes and genera of the tribe Broscini (Coleoptera : Carabidae). Cladistic analysis, taxonomic treatment and biogeographical considerations. Bulletin of the American Museum of Natural History 255:1-90. 
Rolg-Juñent, S. 2004. Los Migadopini (Coleoptera : Carabidae) de América del Sur: Descripción de las estructuras genitales masculinas y femeninas y consideraciones filogenéticas y biogeográficas. Acta Entomológica Chilena 28:7-29.

Roig-Juñent, S. \& Domínguez, M. 2001. Diversidad de la familia Carabidae (Coleoptera) en Chile. Revista Chilena de Historia Natural 74:549-571.

Stern, C.R, Moreno, P.I., Villa-Martínez, R., Sagredo, E.A., Prieto, A. \& Labarca, R. 2011. Evolution of ice-dammed proglacial lakes in Última Esperanza, Chile: implications from the late-glacial R1 eruption of Reclús volcano, Andean austral volcanic zone. Andean Geology 38(1):82-97.

Straneo, S.L. 1979. Notes about classification of the South
American Pterostichini with a key for determination of subtribes, genera and subgenera (Coleoptera: Carabidae). Quaestiones Entomologicae 15:345-356.

VEECH, J.A. \& CRIST, T.O. 2009. PARTITION: software for hierarchical partitioning of species diversity, version 3.0. URL: http://www.users.muohio.edu/cristto/partition.htm Accessed: January 20, 2014.

WhitTAKer, R.H. 1960. Vegetation of the Siskiyou Mountains, Oregon and California. Ecological Monographs 30:279338.

WhitTAKER, R.H. 1972. Evolution and Measurement of Species Diversity. Taxon 21:213-251.

Recibido: 27.06 .14

Aceptado: 06.08.15 